\title{
THE EQUILIBRIUM STATE OF THE EASTERN HALF OF THE ROSS ICE SHELF*
}

\author{
By Robert H. Thomas \\ (Institute for Quaternary Studies, University of Maine at Orono, Orono, Maine 04473, \\ U.S.A.) \\ and Charles R. Bentley \\ 〈Geophysical and Polar Research Center, University of Wisconsin, Madison, Wisconsin 537o6, \\ U.S.A.)
}

\begin{abstract}
Measurements of ice thickness, velocity, snow accumulation rates, and surface strain-rates are used to examine the state of equilibrium of three flow bands of the Ross Ice Shelf. The analysis gives the rate of thickening of the ice shelf in terms of the basal freezing rate, which is unknown. However, indirect evidence suggests that the basal flux ranges from a small value of freezing in the south to a melting rate of about one meter of ice per year at the ice front. If these values are correct then the flow band in the south-east corner of the ice shelf appears to be thickening at an average value of $(34 \pm 15) \mathrm{cm}$ of ice per year. Persistent thickening at this rate must lead to grounding of large areas of the ice shelf. This would restrict drainage from West Antarctic ice streams which feed this part of the ice shelf and these would tend to thicken and advance their grounding lines into the ice shelf. Further north, near the RISP bore-hole site, the ice shelf is probably in equilibrium. The largest flow band is to the south and east of Roosevelt Island, and this also may be in equilibrium if there is significant bottom melting from ice shelf that is more than $100 \mathrm{~km}$ from the ice front.

RÉsumé. L'état d'équilibre de la moitié orientale du Ross Ice Shelf. Par des mesures d'épaisseur de glace, de vitesse, d'accumulation de neige, et de vitesse de déformation en surface, on examine l'état d'équilibre de trois bandes d'écoulement du Ross Ice Shelf. L'analyse donne la vitesse d'épaississement de la glace en fonction de la vitesse de congélation à la base qui est inconnue. Cependant, des indices indirects suggèrent que le flux basal varie depuis une faible valeur de congélation dans le sud jusqu'à une vitesse de fusion d'environ un mètre de glace par an sur le front du glacier. Si ces estimations sont correctes, alors le courant de glace du coin Sud-Est de la banquise semble s'épaissir au rythme moyen de $(34 \pm 15) \mathrm{cm}$ de glace par an. Un épaississement persistant à cette vitesse devrait conduire à appuyer sur le sol de larges zones de la banquise. Ceci restreindrait le drainage par les courants de glace de l'Ouest de l'Antarctique qui nourrissent cette partie de la banquise; ces courants tendent à s'épaissir et à avancer leur ligne de décollement du fond vers l'intérieur de la banquise. Plus loin au Nord, près du site de forage du RISP, la glace est probablement en équilibre. Les plus grands courants d'écoulement sont vers le Sud et l'Est de Roosevelt Island et peuvent aussi être en équilibre s'il y a une fusion au fond significative à partir de la banquise à plus de $100 \mathrm{~km}$ du front glaciaire.

Zusammenfassung. Der Gleichgewichtszustand der östlichen Hälfte des Ross-Schelfeises. Zur Untersuchung des Gleichgewichtszustandes dreier Ströme des Ross-Schelfeises werden Messungen der Eisdicke, der Geschwindigkeit, der Schneeakkumulation und der Deformation an der Oberfläche herangezogen. Die Analyse liefert die Zunahmerate der Schelfeisdicke in Abhängigkeit von Auffrierrate an der Unterseite, die jedoch unbekannt ist. Indirekte Schlüsse lassen jedoch vermuten, dass der Massenfluss an der Unterseite zwischen einem geringen Auffrieren im Süden und einem Schmelzbetrag von etwa I m Eis pro Jahr an der Eisfront liegt. Wenn diese Werte richtig sind, dann scheint der Eisstrom am Südost-Eck des Schelfeises um einen Mittelwert von $(34+15) \mathrm{cm}$ pro Jahr an Dicke zuzunehmen. Eine anhaltende Dickenzunahme in diesem Ausmass muss zum Aufsitzen weiter Gebiete des Schelfeises am Untergrund führen. Damit würde die Transportleistung der Eisströme aus der West-Antarktis, welche diesen Teil des Schelfeises ernähren, drosseln; sie würden an Dicke zunehmen und ihre Aufsitzlinie gegen das Schelfeis vorschieben. Weiter nördlich, an der Stelle des RISP-Bohrloches, befindet sich das Eis vermutlich im Gleichgewicht. Der stärkste Eisstrom liegt im Süden und Osten von Roosevelt Island; er dürfte sich ebenfalls im Gleichgewichtszustand befinden, sofern dort beträchtliches Abschmelzen an der Unterseite des Schelfeises bis zu mehr als $100 \mathrm{~km}$ Frontabstand stattfindet.
\end{abstract}

\section{INTRODUCTION}

The West Antarctic ice sheet is a marine ice sheet resting on rock that was below sea-level before isostatic depression. Weertman (1974) has shown that marine ice sheets are probably unstable, existing usually in a state of growth or retreat, and retreat may be very rapid. Mercer (I968) suggested that complete collapse of the West Antarctic ice sheet could have

* Geophysical and Polar Research Center Contribution No. 347. 
been responsible for the well-documented higher sea-level during the Sangamon Interglacial, and Hughes (1975) believes that the West Antarctic ice sheet may currently be collapsing.

Data from a network of stakes up-stream of "Byrd" station on the West Antarctic ice sheet were interpreted by Whillans (1973) to indicate current thinning of the ice sheet, as was also suggested by work on oxygen isotope ratios and temperatures in the bore hole at "Byrd" station (Robin, I970; Johnsen and others, I972). However, from a re-analysis of the "Byrd" strain-network data, Whillans (1976) concluded that a large region near the ice crest of West Antarctica has been stable for about 30 ooo years. This view is supported by Mayewski's (1975) interpretation of glacial geology in the Transantarctic Mountains, indicating that the Antarctic ice sheet has remained almost unchanged for more than ro ooo years. However, other geological evidence suggests that the West Antarctic ice sheet has decreased in size significantly during the last 12 ooo years, and it may have retreated across the entire area currently occupied by the Ross Ice Shelf since 6 ooo B.P. (Denton and Borns, 1974). Meanwhile, Bentley and others (in press) have concluded that it would be difficult to reconcile isostatic gravity anomalies on the ice shelf with ice thicknesses substantially greater than at present less than about 5 ooo years ago.

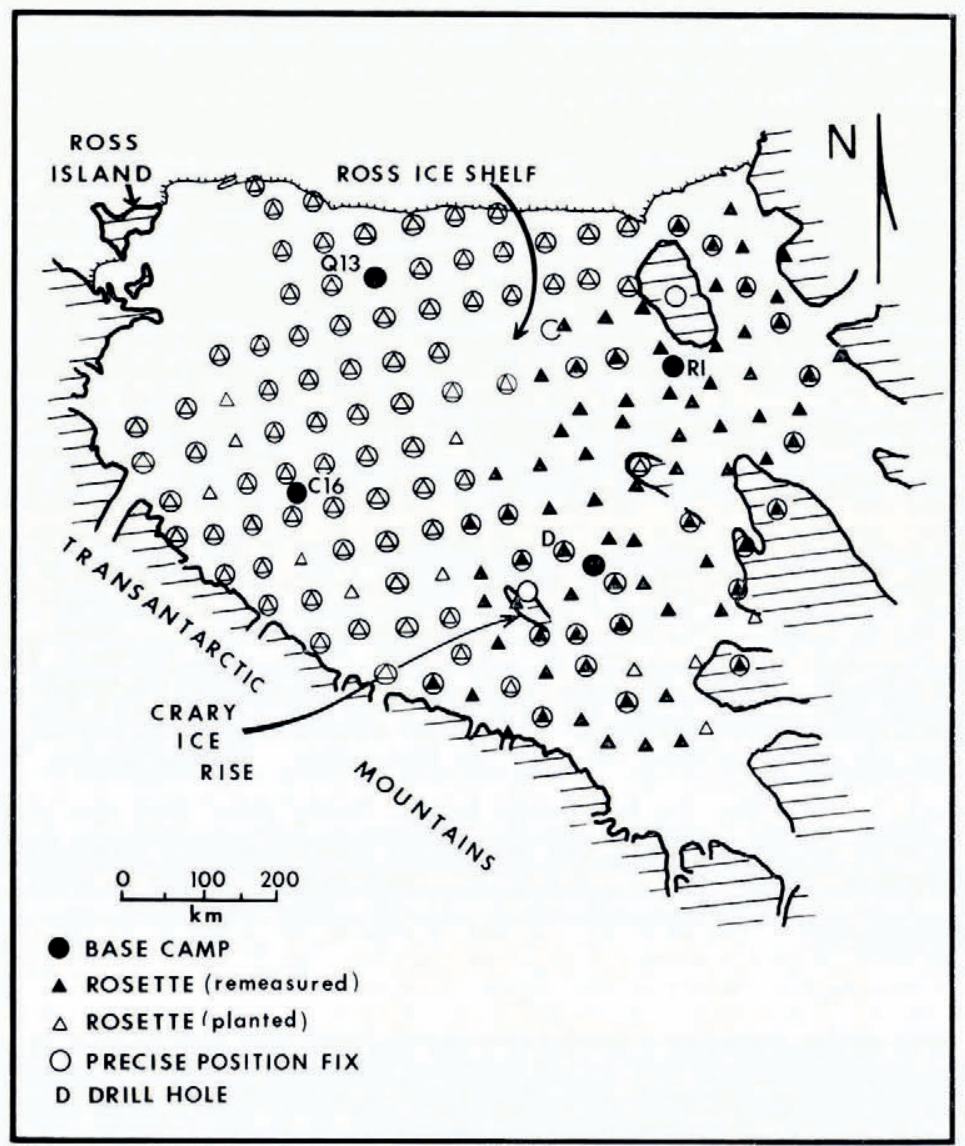

Fig. I. The Ross Ice Shelf, showing positions of RIGGS stations where measurements have been made of ice thickness, depth of sea bed, local gravity, snow-accumulation rates, ice velocity and strain-rates. Since the measurement of ice velocity and strain-rates requires two visits to a station, these data are available only for the stations where "rosettes" have been remeasured.. The remaining stations will be reoccupied during $1977^{-78}$. 
It may be possible to devise a scenario that reconciles these apparently conflicting opinions, but reconciliation is unlikely until there is more information on the past and present equilibrium state of the West Antarctic ice sheet/Ross Ice Shelf system. The acquisition of this information is one of the main aims of the Ross Ice Shelf Project (RISP). This project represents a first attempt to compile a systematic data base for a large and well-defined portion of the Antarctic ice sheet (Zumberge, I97I). The program involves geophysical and glaciological measurements at stations forming a $55 \mathrm{~km}$ grid over the entire surface of the Ross Ice Shelf, with related investigations within and beneath the ice shelf by way of a drill hole. The work on the surface of the ice shelf has been designated the "Ross Ice Shelf Geophysical and Glaciological Survey" (RIGGS), and it includes measurements of ice velocity and strain-rates, snow accumulation rates, surface-snow oxygen-isotope ratios, snow temperatures at $10 \mathrm{~m}$ depth, gravity values, ice thickness, sea-bed topography, and the seismic and electrical properties of the ice. The field work was started in $1973^{-74}$ and, by the end of the 1976-77 season almost all of the planned grid stations (Fig. I) had been visited once for geophysical measurements and for the planting of stake patterns (strain rosettes) to measure ice-shelf strain-rates.

Stations in the eastern half of the ice shelf have been reoccupied for remeasurement of strain rosettes and for precise relocation of some of the stations by satellite tracking. Comparison with initial positions gives absolute velocities at these stations, and velocities at neighboring stations have been interpolated using the strain-rate data. Where interpolated ice velocities and measured values overlapped they generally showed agreement to within $25 \mathrm{~m} \mathrm{year}^{-1}$ (Thomas, 1976[a]). At some of the stations firn cores down to $10 \mathrm{~m}$ depth were taken for surface-snow oxygen-isotope ratios and for identification of the maximum depth of snow containing fall-out from nuclear bombs. This latter measurement gives average snowaccumulation rates (Clausen and Dansgaard, 1977). Sea-bed topography and ice thickness were deduced from seismic measurements and from radio-echo sounding (Clough and Robertson, 1975).

In this paper we shall use the RIGGS measurements to examine the present equilibrium state of the eastern half of the Ross Ice Shelf.

\section{ICE-SHELF EQUILIBRIUM}

The equilibrium state of an ice shelf can be assessed by considering volume-continuity requirements as the ice shelf passes through a stationary vertical column at a distance $x$ along a flow line (Thomas, I977):

$$
\dot{H}+V \frac{\partial H}{\partial x}=\dot{A}+\dot{F}+H \dot{\epsilon},
$$

where $\dot{A}$ is snow accumulation rate, $\dot{F}$ the bottom freezing rate, and $\dot{H}$ the ice-shelf thickening rate, all expressed as thickness of ice per unit time. $H$ is the ice thickness, $\dot{\epsilon}$ the vertical strainrate due to creep of the ice (positive for extension), $V$ the ice velocity along the flow line, and $\partial H / \partial x$ the ice-thickness gradient along the flow line. All of these parameters are functions of $x$. A steady state is represented by $\dot{H}=0$. When $\dot{H}$ is positive the ice shelf is growing thicker with time and vice versa.

Velocity vectors that are calculated from RIGGS data give the routes of flow lines across the ice shelf, and Thomas (I976[b]) solved Equation ( I) to give $(\dot{H}-\dot{F})$ along the flow line that passes through the RISP drill-hole site. The results are very sensitive to values of $\partial H / \partial x$ and $\dot{\epsilon}$ and, since these were interpolated from measurements at nearby grid stations, they possess an indeterminate error which may be large enough to invalidate any conclusions concerning the equilibrium state of the ice shelf. In an attempt to document errors and to minimize them, we shall consider the volume continuity of three flow bands of ice shelf (Fig. 2) 


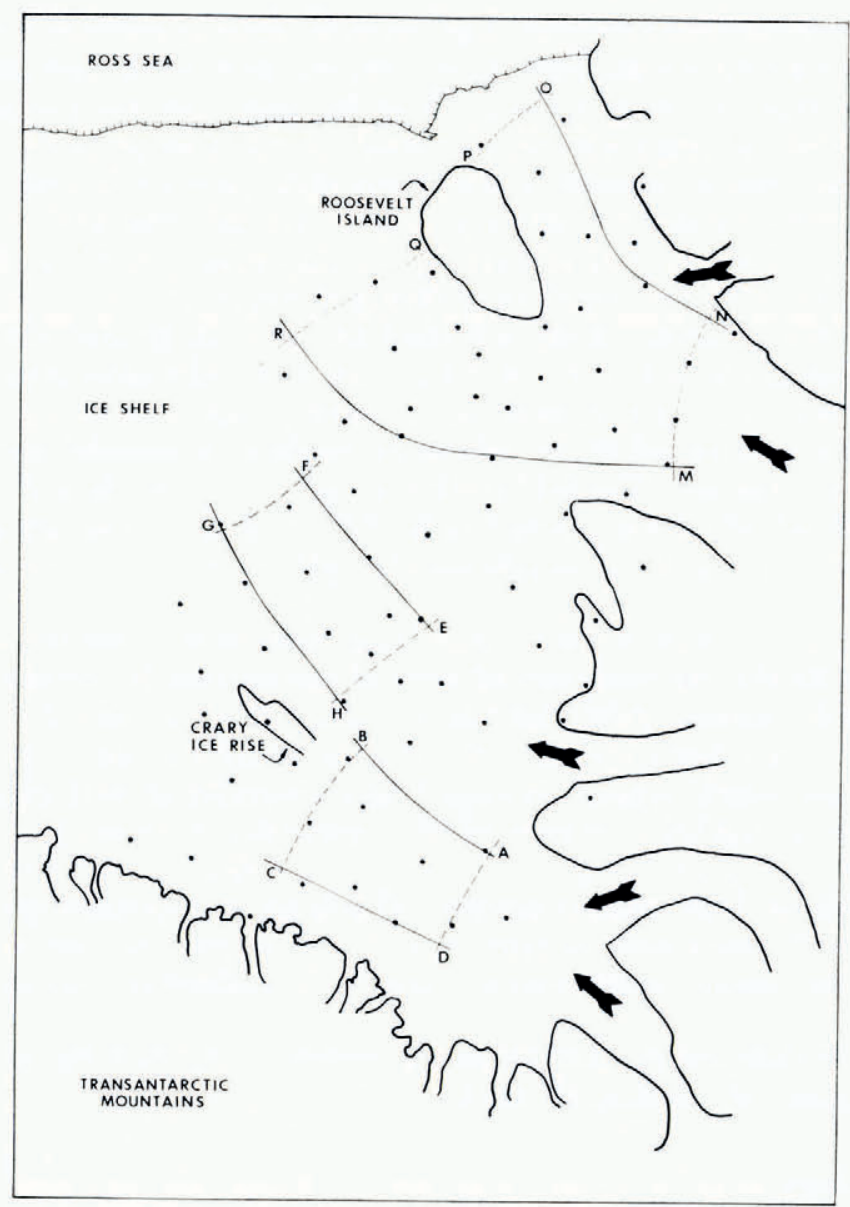

Fig. 2. The eastern side of the Ross Ice Shelf showing positions of RIGGS stations where ice thickness, snow-accumulation rate, ice velocity and strain-rates have been measured. Additional ice thickness data were obtained from several thousand $\mathrm{km}$ of aerial radio-echo sounding. The three bands of ice shelf $A B C D, E F G H$ and $M N O P Q R$ are bounded on each side by flow lines. $A D$ and $B C$ are the entry and exit gates for the band $A B C D$.

that are bounded laterally by flow lines and that each include several of the RIGGS grid stations.

The volumes of ice entering $\left(\dot{Q}_{\mathrm{e}}\right)$ and leaving $\left(\dot{Q}_{\mathrm{o}}\right)$ a band in unit time were calculated by integrating the product of ice velocity and thickness across the entry and exit gates, and the volume of ice added in unit time by snow accumulation $\left(\dot{Q}_{\mathrm{a}}\right)$ is the integral of snow accumulation over the surface area $(S)$ of the band. Snow accumulation rates are from the analysis of $10 \mathrm{~m}$ firn cores and from repeated stake measurements. Where the two methods overlap the results show excellent agreement.

For conservation of volume (Fig. 3) we have

$$
\dot{Q}_{\mathrm{e}}+\dot{Q}_{\mathrm{a}}+\dot{Q}_{\mathrm{b}}=\dot{Q}_{\mathrm{o}}+S \overline{\dot{H}}
$$

where $\dot{Q}_{\mathrm{b}}$ is the volume of ice frozen to the base of the flow band in unit time $(=S \overline{\dot{F}})$, and $\overline{\dot{F}}$ and $\stackrel{\vec{H}}{\vec{H}}$ represent values of $\dot{F}$ and $\dot{H}$ averaged over $S$. This equation can be rewritten as

$$
(\overline{\dot{H}}-\overline{\dot{F}})=\left(\dot{Q}_{\mathrm{e}}+\dot{Q}_{\mathrm{a}}-\dot{Q}_{\mathrm{o}}\right) / S \text {. }
$$




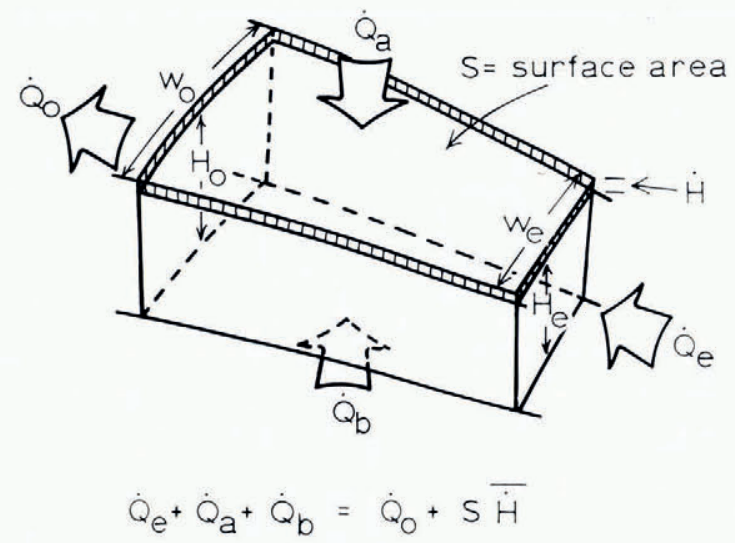

Fig. 3. Volume continuity for a band of ice shelf that is bounded on each side by flow lines.

Values of ice velocity and ice thickness across each gate are shown in Figure 4. They were interpolated from measured values at the grid stations and, for ice thickness, from airborne radio-echo-sounding data. Random errors are $\Delta H= \pm 20 \mathrm{~m}$ for ice thickness, and for velocity $\Delta V$ is based on the consistency of values that are interpolated from different neighboring grid stations (Thomas, I976[a]). Ice thickness errors are probably less than $\pm 20 \mathrm{~m}$ since airborne radio-echo sounding across part of each gate provides excellent control. Errors in $\dot{Q}_{\mathrm{e}}$ and $\dot{Q}_{\mathrm{o}}$ are calculated assuming that the errors in each data point $i$ apply over the region of width $W_{i}$ where $W_{i}$ is half the distance from data point $(i-\mathrm{I})$ to data point $(i+\mathrm{I})$ and that errors are constant within a bracketed region but independent of errors in other regions. Errors in $\dot{Q}_{\mathrm{e}}$ and $\dot{Q}_{\mathrm{o}}$ are then

$$
\Delta \dot{Q}_{\mathrm{e}} \text { or } \Delta \dot{Q}_{0}= \pm\left\{\sum_{i=1}^{i=n}\left(W_{i} V_{i}\left|\Delta H_{i}\right|\right)^{2}+\left(W_{i} H_{i}\left|\Delta V_{i}\right|\right)^{2}\right\}^{\frac{1}{2}},
$$

where $n$ is the number of data points within the gate.

In addition to these random errors we have assumed that the thickness and velocity measurements include systematic errors of $\Delta H_{\mathrm{s}}= \pm \mathrm{I} 5 \mathrm{~m}$ and $\Delta V_{\mathrm{s}}= \pm \mathrm{I} 0 \mathrm{~m}$ year $^{-1}$ respectively, which imply an error in $\left(\dot{Q}_{\mathrm{e}}-\dot{Q}_{\mathrm{o}}\right)$ of

$$
\Delta \dot{Q}_{\mathrm{s}}=\left\{\left[\Delta V_{\mathrm{s}}\left(\bar{H}_{\mathrm{e}} W_{\mathrm{e}}-\bar{H}_{\mathrm{o}} W_{\mathrm{o}}\right)\right]^{2}+\left[\Delta H_{\mathrm{s}}\left(\bar{V}_{\mathrm{e}} W_{\mathrm{e}}-\bar{V}_{\mathrm{o}} W_{\mathrm{o}}\right)\right]^{2}\right\}^{\frac{1}{2}},
$$

where the bars imply averages taken across the appropriate gate. The error in $\dot{Q}_{\mathrm{a}}$ is $\Delta \dot{Q}_{\mathrm{a}}$ and it is calculated assuming a $\pm 15 \%$ error in the average snow-accumulation rate over the band.

Finally there is error in the divergence of the flow lines that define the lateral margins of a band. The flow-line direction at any point is determined mainly by the ice-flow direction at the nearest grid point and this has an error of $\pm(1.5 \text { to } 2.5)^{\circ}$. Thus, a lateral flow line consists of a series of linked segments each of length $L_{j}$ and with a random error of $\Delta D_{j}= \pm(\mathrm{I} .5 \text { to } 2.5)^{\circ}$. The cumulative effect of these errors is to impose an error on the width $W_{\mathrm{o}}$ of the exit gate:

$$
\Delta W_{\mathrm{o}}= \pm\left\{\sum_{j=1}^{j=m}\left(L_{j} \sin \left|\Delta D_{j}\right|\right)^{2}+\sum_{j^{\prime}=1}^{j^{\prime}=k}\left(L_{j^{\prime}} \sin \left|\Delta D_{j^{\prime}}\right|\right)^{2}\right\}^{\frac{1}{2}}=\left\{\Delta W_{1^{2}}+\Delta W_{\mathrm{r}^{2}}\right\}^{\frac{1}{2}}
$$

where $j$ and $j$ ' refer to the "left" and "right" lateral margins, and $m$ and $k$ are the number of segments forming each of these margins. 


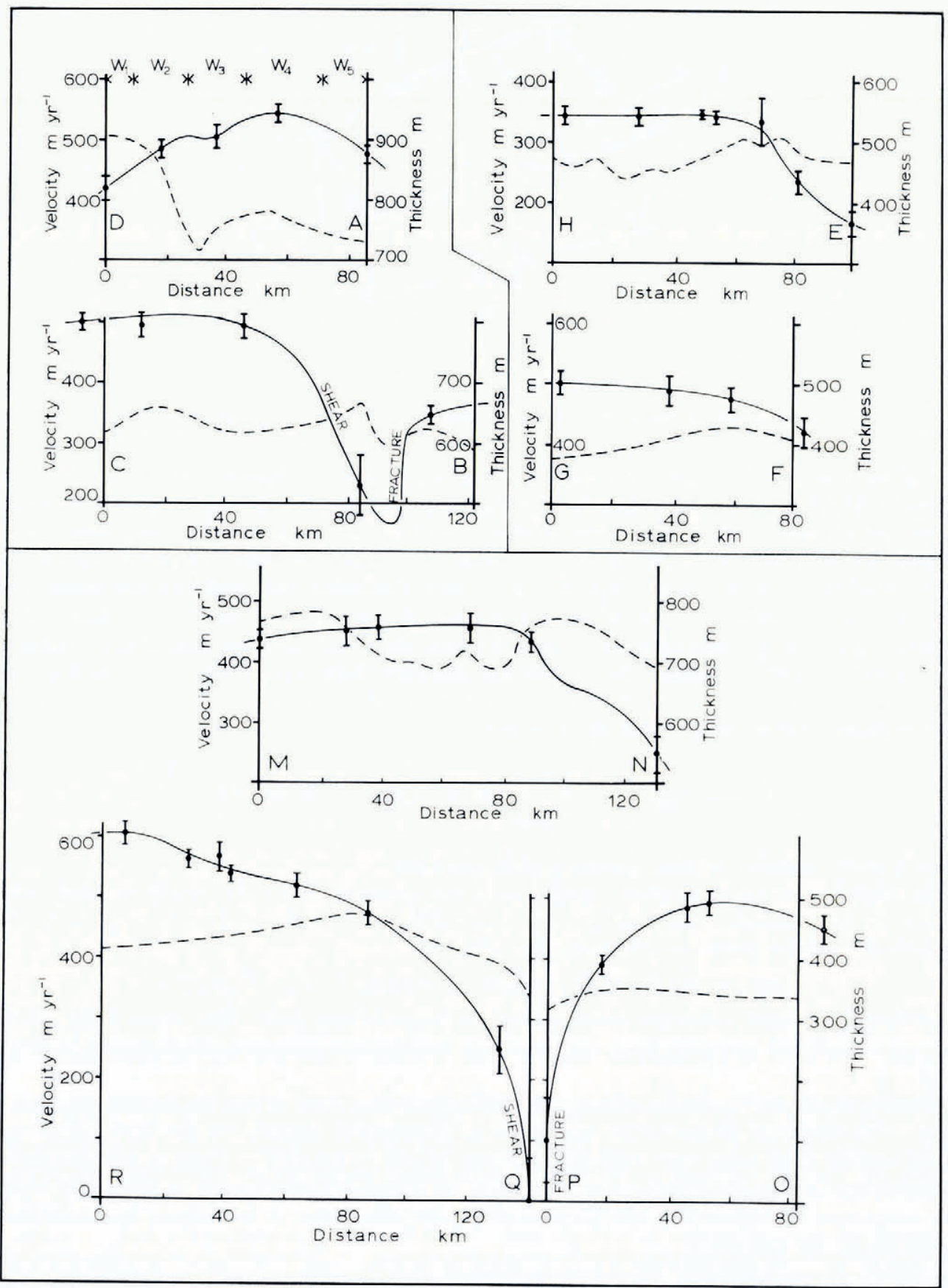

Fig. 4. Ice velocity (solid line) and ice thickness (broken line) plotted against distance across the gates to the ice-shelf flow bands that are shown in Figure 2. The error bars on the velocity data include random errors only. The velocity curves were drawn to conform to measurements of both velocity and velocity gradient across the direction of flow. The velocity minima in sections $C B$ and RO represent the effects of local grounding by Crary Ice Rise and Roosevelt Island. A system of shear crevasses extends for about $20 \mathrm{~km}$ to the south-west of Crary Ice Rise and so we have assumed that shear predominates over this section of the velocity curve. On the other side of the ice rise the ice shelf suffers massive fracture along the north-east grounding line, and shear crevasses are restricted to a narrow zone on the ice-shelf side of this fracture zone. 
The pronounced curvature of flow line $\mathrm{AB}$ (Fig. 2) and the lack of grid stations along the central part of its route introduce an additional uncertainty in the position of $\mathrm{B}$. We have attempted to quantify this error by plotting the flow line first using lateral strain-rates to calculate divergence along the flow-line route and second by assuming that flow direction varies linearly between grid stations. Individual attempts by both authors gave a maximum difference of $8 \mathrm{~km}$ in the position of $\mathrm{B}$ along the gate $\mathrm{BC}$. Here we adopt the central position of $\mathrm{B}$ and we assign an additional error to $W_{0}$ of $\Delta W_{\mathrm{b}}= \pm 5 \mathrm{~km}$. Thus, for the flow band ABCD

$$
\Delta W_{\mathrm{r}^{2}}=\Delta W_{\mathrm{b}^{2}}+\sum_{j^{\prime}=\mathrm{I}}^{j^{\prime}=k}\left(L_{j^{\prime}} \sin \left|\Delta D_{j^{\prime}}\right|\right)^{2} .
$$

For flow band MNOPQR in the north-east of the ice shelf, the margins $\mathrm{P}$ and $\mathrm{Q}$ lie at the grounding line between ice shelf and Roosevelt Island. Ice at $Q$, on the west side of the island, is assumed to have negligible seaward component of velocity, since there is no sign of fracture at the grounding line. On the east side of the island at $\mathrm{P}$, however, the ice shelf is severely fractured and we have assigned to $\mathrm{P}$ an ice velocity of $100 \pm 70 \mathrm{~m}$ year ${ }^{-1}$. The position errors for $\mathrm{P}$ and $\mathrm{Q}$ are assumed to be $\Delta W_{\mathrm{p}}=\Delta W_{\mathrm{q}}= \pm 8 \mathrm{~km}$.

The error to be applied to $(\overline{\dot{H}}-\overline{\dot{F}})$ can now be written

$$
\Delta= \pm \frac{\mathrm{I}}{s}\left\{\Delta \dot{Q}_{\mathrm{e}}^{2}+\Delta \dot{Q}_{\mathrm{o}}^{2}+\Delta \dot{Q}_{\mathrm{s}}^{2}+\Delta_{\mathrm{pq}^{2}}+\left(V_{1} H_{1} \Delta W_{1}\right)^{2}+\left(V_{\mathrm{r}} H_{\mathrm{r}} \Delta W_{\mathrm{r}}\right)^{2}\right\}^{2},
$$

where subscripts 1 and $\mathrm{r}$ refer to the "left" and "right" sides of the exit gate, and $\Delta_{\mathrm{pq}}=0$ except for flow band MNOPQR, where

$$
\Delta_{\mathrm{pq}}{ }^{2}=\left(V_{\mathrm{p}} H_{\mathrm{p}} \Delta W_{\mathrm{p}}\right)^{2}+\left(V_{\mathrm{q}} H_{\mathrm{q}} \Delta W_{\mathrm{q}}\right)^{2} .
$$

For each flow band the values of $S, \dot{A}, \dot{Q}_{\mathrm{a}}, \dot{Q}_{\mathrm{e}}$ and $\dot{Q}_{\mathrm{o}}$ are given in Table I.

TABle I. VAlues of parameters FOR EACH FlOW BAND

$\begin{array}{cl}\text { Flow band } & \\ S & \mathrm{~m}^{2} \\ \dot{A} & \mathrm{~m} \\ \dot{Q}_{\mathrm{a}} & \mathrm{m}^{3} \text { year }^{-} \\ \dot{Q}_{\mathrm{e}} & \mathrm{m}^{3} \text { year }^{-} \\ \dot{Q}_{\mathrm{o}} & \mathrm{m}^{3} \text { year }^{-}\end{array}$

$$
\begin{array}{cc}
A B C D & E F G H \\
\left(14^{8} \pm 5\right) \times 10^{8} & (160 \pm 3) \times 10^{8} \\
0.13 & 0.10 \\
(19 \pm 3) \times 10^{8} & (16 \pm 3) \times 10^{8} \\
(339 \pm 7) \times 10^{8} & (142 \pm 5) \times 10^{8} \\
(308 \pm 20) \times 10^{8} & (157 \pm 10) \times 10^{8}
\end{array}
$$

$M N O P Q R$$$
\begin{gathered}
(550 \pm 11) \times 10^{8} \\
0.165 \\
(91 \pm 14) \times 10^{8} \\
(402 \pm 10) \times 10^{8} \\
(412 \pm 26) \times 10^{8}
\end{gathered}
$$

For section $\mathrm{ABCD}$ in Figure 2 we then have

$$
(\overline{\dot{H}}-\overline{\dot{F}})=+(34 \pm \mathrm{I} 5) \mathrm{cm} \text { of ice per year, }
$$

for section EFGH

and for section MNOPQR

$$
(\overline{\dot{H}}-\overline{\dot{F}})=+(\mathrm{I} \pm 7) \mathrm{cm} \text { of ice per year, }
$$

$$
(\overline{\dot{H}}-\overline{\dot{F}})=+(\mathrm{r} 5 \pm 6) \mathrm{cm} \text { of ice per year. }
$$

Thus, for negligible basal freezing or melting, the ice shelf appears to be thickening with time in the area up-stream of Crary Ice Rise, but is approximately in equilibrium near the RISP drill-hole site. Although no direct measurement of the basal freezing rate has yet been made at the RISP site, temperatures in the upper three-quarters of the ice shelf (personal communication from B. L. Hansen and J. M. Rand in 1976) are fully consistent with a model based on 
the analysis of Crary (196r) taking $\dot{F}=0$ (Bentley, in press). Further south, in the zone of intense fracture immediately north of Crary Ice Rise (Fig. 2), observations of slabs of partially overturned ice shelf reveal layers of debris-laden ice that may have frozen onto the base of the ice shelf as it approached the ice rise (Gaylord and Robertson, 1975). This would imply that $\dot{F}$ is positive, so that up-stream of Crary Ice Rise $\overline{\dot{H}}>(34 \pm 15) \mathrm{cm}$ of ice per year.

This value is larger than the regional snow-accumulation rate and if the ice shelf is thickening at this rate then ice that flows into the region from West Antarctic ice streams is being dammed, probably by Crary Ice Rise. Our result gives no indication of where the thickening rate reaches a maximum. Thickening may be concentrated over a fairly small zone immediately up-stream from Crary Ice Rise or, as concluded by Thomas (1976[b]), it may increase from about zero near the drill-hole site to reach a maximum at the grounding line in the south-east corner of the ice shelf. In either case, within the zone of maximum thickening, the sea bed is separated from the ice shelf by a very narrow wedge of sea-water so that even a small rate of thickening leads to grounding of large areas of ice shelf. If the angle between sea bed and ice-shelf base is $\phi$ and the local ice-shelf thickening rate is $\dot{H}$, the grounding line advances at $\left(\rho_{\mathrm{i}} \dot{H}\right) /\left(\rho_{\mathrm{w}} \sin \phi\right)$, where $\rho_{\mathrm{i}}$ and $\rho_{\mathrm{w}}$ are densities of ice and sea-water respectively. Up-stream from Crary Ice Rise $\phi \approx \mathrm{IO}^{-3}$ radians and near the grounding line in the southeast corner of the ice shelf, $\phi \approx 5 \times \mathrm{IO}^{-4}$ radians. Thus, for zero bottom melting, the average regional thickening rate implies grounding-line advance rates of about $300 \mathrm{~m}$ year ${ }^{-1}$ upstream of Crary Ice Rise or about $600 \mathrm{~m} \mathrm{year}^{-1}$ for the south-east corner of the ice shelf. Such large advance rates can only be sustained by continued rapid ice flow from the West Antarctic ice streams. If the grounding lines of these ice streams are advancing into the ice shelf then we might expect the resultant areas of grounded ice shelf to offer increased resistance to flow down the ice streams. This would act as a negative-feedback mechanism and tend to stabilize the grounding-line position. If ice-shelf thickening is confirmed in the area immediately up-stream of Crary Ice Rise however, it could continue undiminished since icestream flow rates would not immediately be affected. Ultimately, however, the increased size of Crary Ice Rise would tend to restrict ice-stream flow rates. One of the authors (R.H.T.) has traveled extensively over the surface of the ice shelf seeking stations in order to remeasure strain rosettes. During these journeys many small ice rises, where the ice shelf had locally grounded, were encountered within the region extending $200 \mathrm{~km}$ up-stream of Crary Ice Rise and some of these, although well marked by patterns of strand cracks, showed little of the increase in surface elevation that gives ice rises their name. This may indicate that the ice shelf had but recently run aground and that sufficient time had not yet elapsed to allow the ice rise to assume its equilibrium surface profile.

Further north, near Roosevelt Island, conditions may be favorable for bottom melting so that $\dot{F}$ becomes negative. If the ice shelf in this area is in equilibrium, then the average bottom-melting rate beneath the ice-shelf portion of flow band MNOPQR is $(15 \pm 6) \mathrm{cm}$ of ice per year. This can be compared with estimates of bottom-melting rate near the seaward ice front at Little America V of about one meter per year (Crary, I96I).

\section{Summary}

Balance calculations for the eastern half of the Ross Ice Shelf indicate that the south-east corner of the ice shelf may be growing thicker by more than $30 \mathrm{~cm}^{-1} \mathrm{ear}^{-1}$. If this is so then it is probably due to the damming effects of Crary Ice Rise which may have formed comparatively recently at a point where the ice shelf ran aground on an isostatically-rising sea-bed ridge. Our results do not indicate where thickening is greatest. It may be immediately up-stream of the ice rise in which case the ice-rise grounding line is advancing about 300 $\mathrm{m}$ year $^{-\mathrm{I}}$ into the ice shelf in a south-easterly direction, or it may be along the grounding line 
of West Antarctic ice streams that drain into this part of the ice shelf, and this would imply local advance of the West Antarctic ice sheet in a north-westerly direction. In either case large areas of comparatively flat grounded ice will be formed and these must ultimately offer increased resistance to the flow of ice into the ice shelf, so that ice velocities decrease and ice piles up in the lower reaches of the ice streams. In this way the advance would become consolidated and an equilibrium grounding-line position would finally be achieved. Sea-bed topography suggests that, if advance is indeed taking place, it could continue until Crary Ice Rise has been absorbed by the West Antarctic ice sheet, which event should signal a furore of activity from the various Place-Names Committees. If for no other reason this problem deserves further attention and the RIGGS data provide excellent guidelines to where additional measurements are required.

The ice shelf to the north of Crary Ice Rise, including the site of the RISP drill hole, appears to be approximately in equilibrium and this also may be so for the ice shelf near Roosevelt Island, where our results indicate either thickening or bottom melting of approximately $15 \mathrm{~cm}$ of ice year ${ }^{-1}$.

Hughes (1975) suggested that the West Antarctic ice sheet currently may be collapsing, but our results provide no support for this hypothesis; indeed the ice sheet appears to be advancing into the south-east corner of the Ross Ice Shelf. However, we should note that growth at the edge of the West Antarctic ice sheet may be taking place at the same time as thinning of the central portions, which currently may be responding to earlier retreat of the ice-sheet margins (Thomas, 1976[b]). If this is the case then the West Antarctic ice sheet could be slumping to cover a larger area but with a lower summit elevation.

\section{Acknowledgements}

This work was supported by National Science Foundation grants DPP $76-23047$ and $\mathrm{OPP}_{72-0} 802$. We are indebted to the numerous field assistants who helped us to gather data from the Ross Ice Shelf. We also thank W. MacDonald of the United States Geological Survey, who provided the precise position fixes on the ice shelf that were used to calculate ice velocities, and W. Chapman of the U.S.G.S., who allowed us to use strain-rate measurements that he had made at a station to the east of Roosevelt Island. An anonymous referee made suggestions that have helped us to clarify the text.

MS. received 20 October 1977 and in revised form 24 April 1978

\section{REFERENCES}

Bentley, C. R. In press. In situ measurements of the activation energy for d.c. conduction in polar ice. Fournal of Glaciology, Vol. 21, No. 87.

Bentley, C. R., and others. In press. Isostatic gravity anomalies on the Ross Ice Shelf, Antarctica, by C. R. Bentley, J. D. Robertson and L. L. Greischer. [Paper presented at the third Symposium on Antarctic Geology and Geophysics, Madison, Wisconsin, August 1977.]

Clausen, H. B., and Dansgaard, W. r977. Less surface accumulation on the Ross Ice Shelf than hitherto assumed. [Union Géodésique et Géophysique Internationale. Association Internationale des Sciences Hydrologiques. Commission des Neiges et Glaces.] Symposium. Isotopes et impuretés dans les neiges et glaces. Actes du colloque de Grenoble, août/septembre 1975 , p. 1 72-76. (IAHS-AISH Publication No. 118 .) Clough, J. W., and Robertson, J. D. 1975. RISP geophysical survey. Antarctic fournal of the United States, Vol. Io,
No. 4, p. 153-55.

Crary, A. P. 1961. Glaciological studies at Little America station, Antarctica, 1957 and 1958. IGY Glaciological Report Series (New York), No. 5.

Denton, G. H., and Borns, H. W., jr. 1974. Former grounded ice sheets in the Ross Sea. Antartic Journal of the United States, Vol. 9, No. 4, p. 167.

Gaylord, D. R., and Robertson, J. D. r975. Sediments exposed on the surface of the Ross Ice Shelf, Antarctica. Fournal of Glaciology, Vol. 14 , No. 71, p. 332-33.

Hughes, T. J. 1975. The west Antarctic ice sheet: instability, disintegration, and initiation of ice ages. Reviews of Geophysics and Space Physics, Vol. 13, No. 4, p. 502-26. 
Johnsen, S. J., and others. 1972. Oxygen isotope profiles through the Antarctic and Greenland ice sheets, [by] S. J. Johnsen, W. Dansgaard, H. B. Clausen, C. C. Langway, Jr. Nature, Vol. 235, No. 5339, p. 429-34. Mayewski, P. A. 1975. Glacial geology and late Cenozoic history of the Transantarctic Mountains, Antarctica. Ohio State University. Institute of Polar Studies. Report No. 56.

Mercer, J. H. 1968. Antarctic ice and Sangamon sea level. Union de Géodésie et Géophysique Internationale. Association Internationale d'Hydrologie Scientifique. Assemblée générale de Berne, 25 sept.-7 oct. 1967. [Commission des Neiges et Glaces.] Rapports et discussions, p. 217-25. (Publication No. 79 de l'Association Internationale d'Hydrologie Scientifique.)

Robin, G. de Q. 1970. Stability of ice sheets as deduced from deep temperature gradients. [Union Géodésique et Géophysique Internationale. Association Internationale d'Hydrologie Scientifique.] [International Council of Scientific Unions. Scientific Committee on Antarctic Research. International Association of Scientific Hydrology. Commission of Snow and Ice.] International Symposium on Antarctic Glaciological Exploration (ISAGE), Hanover, New Hampshire, U.S.A., 3-7 September 1968, p. 141-51. (Publication No. 86 [de l'Association Internationale d'Hydrologie Scientifique].)

Thomas, R. H. 1976[a]. Ice velocities on the Ross Ice Shelf. Antarctic Journal of the United States, Vol. I I, No. 4, p. $279-81$.

Thomas, R. H. 1976[b]. Thickening of the Ross Ice Shelf and equilibrium state of the west Antarctic ice sheet. Nature, Vol. 259, No. 5540, p. 180-83.

Thomas, R. H. 1977. Calving-bay dynamics and ice-sheet retreat up the St. Lawrence Valley system. Géographie Physique Quaternaire, Vol. 31, Nos. 3-4, p. 347-56.

Weertman, J. 1974. Stability of the junction of an ice sheet and an ice shelf. Fournal of Glaciology, Vol. 13, No. 3, p. $3^{-1} \mathrm{I}$.

Whillans, I. M. 1973. State of equilibrium of the west Antarctic inland ice sheet. Science, Vol. 182, No. 41 I I, p. $476-79$.

Whillans, I. M. I976. Radio-echo layers and the recent stability of the west Antarctic ice sheet. Nature, Vol. 264,

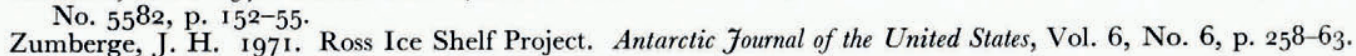

